\title{
HTLV-I associated myelopathy in the northern region of Brazil (Belém-Pará): serological and clinical features of three cases
}

\author{
Mielopatia associada ao HTLV-I na região Norte do Brasil (Belém-Pará): \\ aspectos clínicos e sorológicos de três casos
}

\author{
Ricardo Ishak', Fernando Cavalcante ${ }^{2}$, Antonio Carlos R. Vallinoto', \\ Vânia Nakauth Azevedo ${ }^{1}$ and Marluísa O. Guimarães Ishak ${ }^{1}$
}

\begin{abstract}
Three patients (males, black, ages 37, 40 and 57) attended a university clinic with a progressive paraparesis of obscure origin. One patient who referred disease duration of more than 16 years, showed diminished deep reflexes, bilateral Babinski's sign, diminished sensation of vibration, abnormal bladder function and back pain. The other two patients (with one and six years of disease duration) complained of weakness in one leg, increased deep reflexes and back pain. Babinski's sign and bladder disturbance were also present in the patient with six years of disease. Blood samples tested by an enzyme immune assay and a discriminatory Western blot were positive for HTLV-I. The familial analysis of one patient showed a possible pattern of sexual and vertical transmission of the virus. To the best of our knowledge, these are the first cases of a proven association between HTLV-I and TSP/HAM in Belem, Para, and emphasize the need to actively look for cases of neurological disease associated to the virus.
\end{abstract}

Key-words: HTLV-I. Myelopathy. TSP/HAM. Neurological disease.

Resumo Três pacientes (masculinos, negros, idades 37, 40 e 57) foram atendidos em uma clínica universitária com uma paraparesia progressiva de origem obscura. Um paciente que referiu a duração da doença por mais de 16 anos, mostrou hiporreflexia, sinal de Babinski bilateral, uma sensibilidade vibratória diminuídă, disfunção urinária e dor lombar. Os outros dois pacientes (com um e seis anos de duração da doença) queixavam-se de fraqueza em uma das pernas, hiperreflexia e lombalgia. Sinal de Babinski e distúrbio urinário estavam também presentes no paciente com seis anos de doença. Amostras de sangue testadas por ELISA e Western blot foram positivos para HTLV-I. A análise familiar de um dos pacientes, mostrou um possível padrão de transmissão sexual e vertical do vírus. Ao nosso conhecimento, estes são os primeiros casos comprovados de uma provável associação entre o HTLV-I e PET/MAH em Belém, Pará, e enfatiza a necessidade de uma busca ativa de casos de doenças neurológicas associadas ao vírus na região.

Palavras-chaves: HTLV-I. Mielopatia. PET/MAH. Doença neurológica.

Human T-cell lymphotropic virus, type I (HTLV-I) is associated to a neoplastic disorder (Adult T-cell Leukemia and Lymphoma-ATLL), to a characteristic uveitis and a neurological chronic disease, Tropical Spastic Paraparesis or HTLV-I Associated Myelopathy (TSP/HAM). This condition is a chronic myelopathy without spontaneous remission, characterized by a slowly progressive paraparesis, affecting mainly the pyramidal tracts and associated to a variable sphincter disturbance and abnormalities of the sensory system $^{56}$. In general, TSP/HAM occurrence follows the same geographical distribution of the virus, presenting high frequencies in Asia, West Indies, America, and Melanesia ${ }^{10}$, it affects predominantly individuals from 35 to 49 years of age, with a male/female ratio of 2.5 to $3.0: 1$, and shows a high frequency among Negroes, mixed race and Asians, although it has also been found among Caucasians ${ }^{912}$.

In Brazil, the first cases of proven TSP/HAM were reported in $1989^{2} 4$. Furthermore, clinical and

\footnotetext{
1. Laboratório de Virologia do Departamento de Patologia do Centro de Ciências Biológicas da Universidade Federal do Pará, Belém, PA, Brasil. 2. Hospital Universitário Betina Souza e Ferro, Belém, PA.

Address to: Ricardo Ishak. Caixa Postal 13005, 66040-970 Belém, PA, Brasil.

Tel: 5591 211-1142, Fax: 5591 224-9739.

Recebido para pulicação em 17/5/2001.
} 
seroepidemiological studies have shown cases of TSP linked to HTLV-I antibody detection, in Recife, Salvador, Rio de Janeiro, Sao Paulo and Porto Alegre ${ }^{18}$.
The present work describes, for the first time, in Belém, Pará (Brazil), a positive association of HTLV-I with three cases of chronic myelopathy.

\section{MATERIAL AND METHODS}

Patients examined. Three patients attending a university outpatient clinic (at the Betina Souza e Ferro Hospital, UFPA) with complaints of chronic gait disturbances of obscure origin for more than 6 months, were neurologically examined. In addition, nine other relatives of two of the patients were examined in order to detect clinical signs of neurological abnormalities. Demographic data regarding these patients are presented in Table 1.

Table 1 - Demographic and epidemiological data of three patients with neurological disease associated to HTLV-I in Belém, Pará, Brazil.

\begin{tabular}{lccc}
\hline Characteristic & Patient 1 & Patient 2 & Patient 3 \\
\hline Sex & male & male & male \\
Race & negro & negro & negro \\
Age & 40 & 37 & 57 \\
Origin & Buriti Bravo-MA & Santa Cruz do Arari-PA & Cachoeira do Arari-PA \\
Employment & general services & fisherman & fisherman \\
History of blood transfusion & no & no & yes \\
Duration of disease (years) & 1 & 6 & 16 \\
\hline
\end{tabular}

Serological assays. Serum samples were collected from all three patients and nine of their relatives. Serological diagnostic tests were provided and included an enzyme immunoassay (EIA, Ortho Diagnostic, USA) and a discriminative Western blot (Genelab 2.4, Singapore) that was capable of distinguishing serological reactivity between HTLV-I and HTLV-II, as previously described?

\section{RESULTS}

Clinical features. The clinical features of the three patients during medical examination and counseling are summarized in Tables 2 and 3, and they presented a neurological disorder clinically diagnosed as Tropical Spastic Paraparesis. None of the examined relatives displayed any sign or symptom compatible with TSP/ HAM or any minor neurological abnormalities.

Serological assay. All three patients showed antibodies reactive to HTLV-I/II when tested using the EIA. Western blot serological reactivity was confirmed

Table 2 - Clinical symptoms observed in three patients with TSP/HAM in Belém, Pará, Brazil.

\begin{tabular}{lcc}
\hline Clinical characteristic & Patient 1 & Patient 2 \\
\hline Difficulty in walking/running during school age & - & - \\
Weakness of the legs within six months of onset of the disease & + & + \\
Leg cramps & + & + \\
Lower limb paresthesis & + & + \\
Back pain with irradiation to the legs & - & + \\
Bladder dysfunction & + & + \\
Male impotence & + \\
\hline
\end{tabular}

+ present; - absent

to be against HTLV-I. The sera of the wife and son of patient nr. 1 showed reactivity to HTLV on the EIA. The Western blot serological reactivity showed an indeterminate pattern (wife) and a characteristic HTLV reaction (son), according to the manufacturer's recommendations for interpretation of the test (Figure 1).

\section{DISCUSSION}

The association of HTLV-I to a progressive neuroencephalopathy has been constantly described in Brazil since the initial detection in 19891234. The clinical and epidemiological data observed to date, appears to be similar to the cases of TSP/HAM described worldwide ${ }^{11} 12$. In the present paper three cases of clinically diagnosed myelopathy were described with characteristic symptoms of lower limb paresthesis and weakness, incapacity of walking, diminished deep reflexes, bilateral Babinski's sign, back pain, bladder dysfunction and impotence. The three patients fulfilled the clinical criteria as well as presenting serological evidence of HTLV-I infection, sufficient to categorize these as cases of TSP/HAM.

Epidemiological and demographic information also coincide with what is usually observed elsewhere; in that they were black males, with an age range of 37 
Table 3 - Neurological abnormalities present in three patients with TSP/HAM in Belém, Pará, Brazil.

\begin{tabular}{|c|c|c|c|}
\hline Clinical characteristic & Patient 1 & Patient 2 & Patient 3 \\
\hline Psychic analysis & Normal & Normal & Normal \\
\hline \multicolumn{4}{|l|}{ Motricity of lower limbs } \\
\hline spastic gait & A & A & $\mathrm{P}$ \\
\hline weakness & $\mathrm{P}$ & $\mathrm{P}$ & $\mathrm{P}$ \\
\hline hyperreflexia & $\mathrm{P}$ & $\mathrm{P}$ & $\mathrm{P}$ \\
\hline hyporreflexia & A & A & $P$ \\
\hline hypertonia & A & A & $\mathrm{P}$ \\
\hline \multicolumn{4}{|l|}{ Capacity of walking } \\
\hline conserved but limited & $\mathrm{Y}$ & $\mathrm{N}$ & $\mathrm{N}$ \\
\hline use of one or two crutches & $\mathrm{N}$ & $\mathrm{Y}$ & $\mathrm{Y}$ \\
\hline incapacity & $\mathrm{N}$ & $\mathrm{N}$ & $\mathrm{N}$ \\
\hline Babinski's sign & $\mathrm{Y}$ & $\mathrm{Y}$ & $\mathrm{Y}$ \\
\hline Muscle atrophy & $\mathrm{N}$ & $\mathrm{Y}$ & $\mathrm{Y}$ \\
\hline Superficial sensibility loss in the lower limbs & Normal & Normal & Normal \\
\hline Deep sensibility loss in the lower limbs & D & D & D \\
\hline \multicolumn{4}{|l|}{ Autonomic disturbances } \\
\hline bladder dysfunction & A & $P$ & $P$ \\
\hline constipation & A & A & $\mathrm{P}$ \\
\hline impotence & $\mathrm{P}$ & $\mathrm{P}$ & $\mathrm{P}$ \\
\hline
\end{tabular}

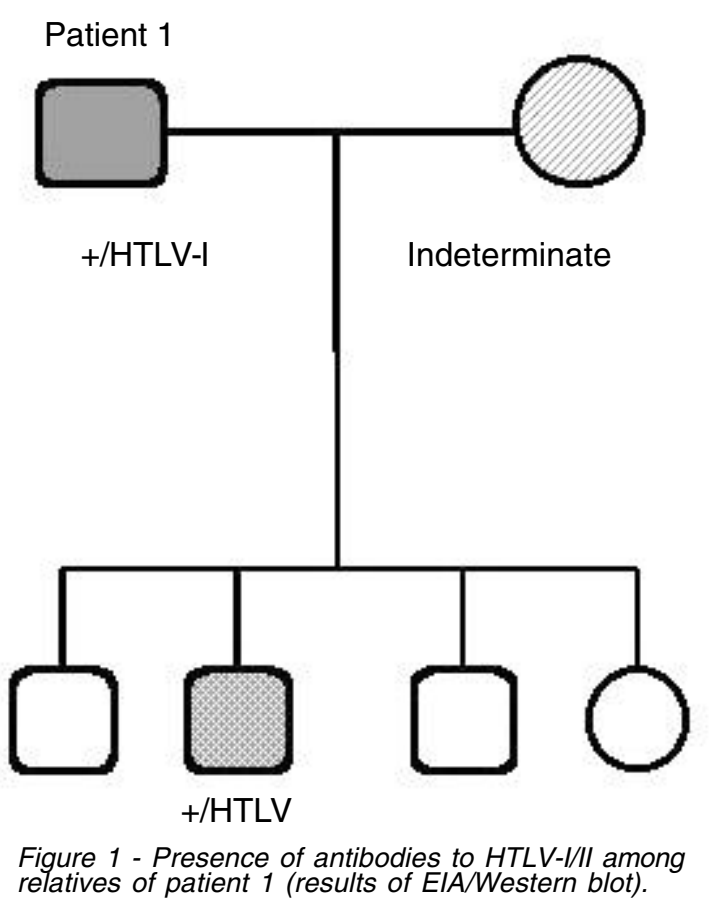

to 57 years. The patients resided outside large urban areas, lacking in adequate clinical and laboratory facilities. The association of subtle symptoms at onset of disease, poor diagnostic resources and low income are common and complicating factors that contribute towards the absence of other cases described in the northern region of the Country.

Screening for the presence of antibodies to HTLV among nine relatives of patients 1 and 3 showed that patient 3 was the sole case in the family and transmission of the virus occurred possibly through the parenteral or sexual path. The wife and son (8 years of age) of patient 1 showed evidence of HTLV infection and vertical transmission had probably occurred.

As far as we are aware, these are the first cases of a proven association between HTLV-I and myelopathy (TSP/HAM) described in Belem, but the occurrence of 
this or other neurological disorders related to HTLV-I are probably more common. The dissemination of proper information for the clinical and laboratory procedures should be sufficient to improve diagnostic skills, however it is necessary to emphasize the need for a close surveillance and to undertake a further active search for cases of neurological diseases associated to HTLV$\mathrm{I}$, in this particular geographical region of the Country.

\section{ACKNOWLEDGEMENTS}

To Dr. Carlos M.C. Costa for his careful revision of the manuscript. The present work was partially supported by grants from the Federal University of Pará and NIH, USA.

\section{REFERENCES}

1. Araújo AQC, Andrada-Serpa MJ. Tropical Spastic Paraparesis/ HTLV-I Associated Myelopathy in Brazil. Journal of Acquired Immune Deficiency Syndromes and Human Retrovirology 13 (supl): S33-S37, 1996.

2. Castro LHM, Chaves CJ, Callegaro D, Nóbrega JPS, Scaff M. HTLV-I associated myelopathy in Brazil, a preliminary report. Arquivos de Neuropsiquiatria 47: 501-502, 1989.

3. Costa CMC, Cardoso do Vale O, Goubau P, Desmyter J, Carton H. HTLV-I and tropical paraparesis in Fortaleza (northeastern Brazil). Journal of Tropical and Geographical Neurology 1:45-48, 1991.

4. Costa CMC, Salgueiro MR, Carton H, Vale OC, Arruda AM. Tropical spastic paraparesis in northeastern Brazil. Arquivos de Neuropsiquiatria 47: 134-138, 1989.

5. Ferreira Jr OC, Planelles V, Rosenblatt JD. Human T-cell leukemia viruses: epidemiology, biology and pathogenesis. Blood Reviews 11: 91-104, 1997.

6. Gessain A, Vernant JC, Maurs L, Barin F, Gout O, Calender A. Antibodies to Human T-Lymphotropic Virus Type I in patients with tropical spastic paraparesis. Lancet 359: 407-409, 1985.

7. Ishak R, Harrington Jr WJ, Azevedo VN, Eiraku N, Ishak MOG, Guerreiro JF, Santos SEB, Kubo T, Monke C, Alexander S,
Hall WW. Identification of human T-cell lymphotropic virus type Ila infection in the Kayapo, an indigenous population of Brazil. AIDS Research and Human Retroviruses 11: 813-821, 1995.

8. Menna-Barreto M, Doval A, Rabolini G, Bianchini O. HTLV-I associated myelopathy in Porto Alegre (southern Brazil). Arquivos de Neuropsiquiatria 53: 771-776, 1995.

9. Menna-Barreto M, Meurer L, Mattos V. Insuficiência Respiratória Aguda complicando TSP/HAM. In: Resumo do V Simpósio Internacional sobre HTLV no Brasil (supl): S-03, 1998.

10. Mongtomery RD. The epidemiology of myelopathy associated with human T-lymphotropic virus 1. Transactions of the Royal Society of Tropical Medicine and Hygiene 87: 154-159, 1993.

11. Taylor GP. The epidemiology of HTLV-I in Europe. Journal of Acquired Immune Deficiency Syndromes and Human Retrovirology 13 (supl): S08-S14, 1996.

12. Touzé E, Gessain, Lyon-Caen O, Gout O. Tropical Spastic Paraparesis/HTLV-I-Associated Myelopathy in Europe and Africa: Clinical and Epidemiologic Aspects. Journal of Acquired Immune Deficiency Syndromes and Human Retrovirology 13 (supl): S38S45, 1996. 